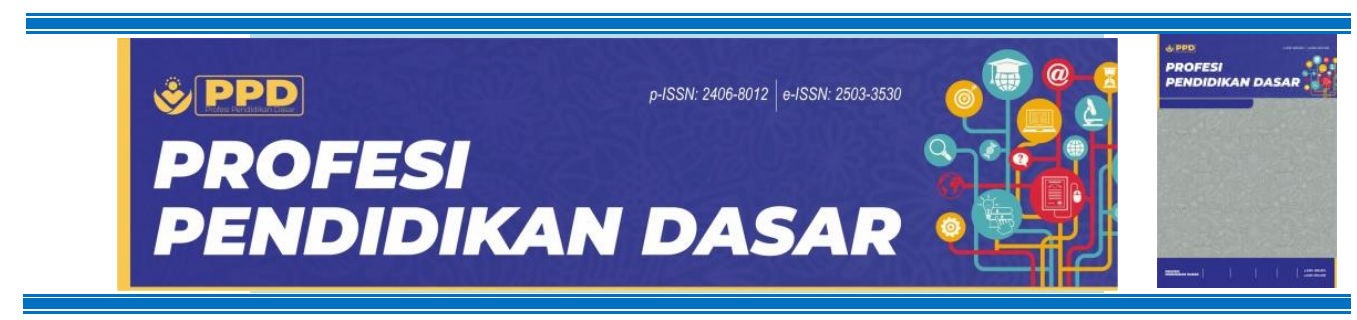

\title{
E-Money Tab As An Attendance Tracker For Elementary School Students
}

\author{
Minsih $^{1^{*}}$, Fiki Nur Rahmawati², Rusnilawati ${ }^{3}$ \\ 1,2,3 Universitas Muhammadiyah Surakarta, Surakarta, Indonesia \\ *Email: $\underline{\text { min139@ums.ac.id }}$
}

\begin{tabular}{|c|c|}
\hline $\begin{array}{l}\text { Submitted: } 2020-10-01 \\
\text { Accepted: } 2020-12-03 \\
\text { Published: } 2021-07-25\end{array}$ & DOI: 10.23917/ppd.v8i1.12227 \\
\hline Keywords: & Abstract \\
\hline $\begin{array}{l}\text { e-money; } \\
\text { tablet; } \\
\text { attendance; } \\
\text { discipline; } \\
\text { students }\end{array}$ & $\begin{array}{l}\text { This study aims to describe: 1) the process of using e-money tab, 2) the } \\
\text { advantages and disadvantages of using the e-money tab, 3) the impacts of } \\
\text { using the e-money tab. This study was conducted as a qualitative study } \\
\text { facilitating a phenomenological research design. Data was collected through } \\
\text { interviews, live observation and analysis of documents. Study subjects included } \\
\text { the principal, the IT team and students of } 1 \text { Muhammadiyah Elementary School, } \\
\text { Ketelan Surakarta (Elementary School of Muhammadiyah } 1 \text { Ketelan Surakarta) } \\
\text { and was conducted on location. Results of this study showed that: a) the use of } \\
\text { e-money tabs as an attendance tracker can only be accessed at school and } \\
\text { requires a strong internet network, b) an advantage to the use of e-money tab } \\
\text { as an attendance tracker is being able to track attendance of students with } \\
\text { ease, allowing teachers to ensure discipline and parents to monitor the arrival } \\
\text { and departure time of their children to and from school. On the other hand, a } \\
\text { disadvantage to this system is the instability of the internet network especially } \\
\text { when multiple students are using the e-money tab at the same time, causing } \\
\text { error in the server, c) the e-money tab has impacted the process of attendance } \\
\text { tracking, in which it has maintained and improved discipline of students. }\end{array}$ \\
\hline
\end{tabular}

\section{INTRODUCTION}

\section{Background}

Education can be regarded as an essential necessity. The education process can influence change in an individual towards a positive character. As explained by Sukmadinata (2011: 4), education functions as a tool for students to develop their potential, skills and self-character in a positive manner for both themselves and their environment. Due to this, education has to be improved and developed to situate with the change in eras. Good education will produce high quality human resources. According to Samino (2015: 1), education is absolutely necessary for the building of maturity in students. Education can shape their characters and improve their moralities, knowledge and understanding of

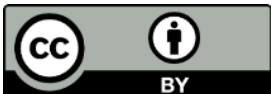

This work is licensed under a Creative Commons Attribution 4.0 International License 
technology. The process of change and improvement in education aims to enhance the quality of education in Indonesia.

Character building refers to the attempt done by teachers to influence their students positively while at school. This is in line with the comments by Minsih (2015: 112), who explained that schools are an educational institute that play a big role in developing a student's personality. The characters of students must be cultivated from a young age so that they form exceptional personalities. This is also in accordance with what was mentioned by Widyahening (2016: 177), in which character building can be initiated from an early age, even while still a baby or in the womb, to produce people with positive characters. The development of a good character will influence the child's personality when they grow older. This is because character is something that sticks to a person's personality and behavior. An activity that is done repeatedly will become a habit, and a habit that becomes a routine will become part of a person's character (Putri, 2018: 41). Character building is one of the main components that needs to be developed in life.

One characteristic value necessary to be developed in discipline. Discipline needs to be developed in schools so that students will have good characters. In accordance with Abbas (2018: 240), discipline needs to be developed in schools to produce students that are educated and disciplined. Discipline is the act of controlling oneself and the individual's ability to follow rules (Annisa, 2018: 108). The lack of self-control in students will cause them to deviate from school rules, such as coming to school late when lessons have started (Putra, 2019: 110). Character building is not the sole responsibility of educators, but of everyone around the child's life. This includes family, members of the school and the child's community (Wuryandani, 2014: 288). The cultivation of discipline in students must always be supervised and proper examples must be set by all to guide these students. This way, students will not feel burdened and will understand that discipline is a mutual commitment which is applied to all members of the school. Discipline is a character that can be shaped during the education process. In this era, there are many ways to take advantage of technology to improve the quality of education.

The development of technology affects all aspects in life, especially in the field of education. The advancement of technology must be adapted, as it will advance science as well. The rapid development of facilities in many different fields in life is a form of advancement in technology and science (Mubarok, A. 2017:230). New innovations that have been developed well and have been continuously supervised can improve the quality of education in Indonesia. The advancement of technology in education improves its quality when applied in schools. This is in line with Budiman (2017: 32), whereby the development of information technology in this era affects the field of education.

Elementary School of Muhammadiyah 1 Ketelan Surakarta is not just prestigious in academics, but also in non-academic matters. As technology develops, this school always adapts to new programs facilitating technology. Among which are the use of e-money as a main method of transaction in school, e-learning as an online platform for studies, e-infaq as an online method of infaq payments, e-library as a platform for students to borrow books from the library, e-rapot as a method of end of semester evaluations, and their latest project, the e-money tab as a student attendance tracker. The use of technology by Elementary School of Muhammadiyah 1 Ketelan Surakarta has been supported by the study by Rahmawati (2020: 5), who investigated the advantages of technology in the process of student assessment also known as electronic reporting (elektronik rapot / e-rapot).

With the demand for technology development in the 4.0 revolutionary era, SD Muhammadiyah 1 Ketelan designed the e-money tab. The availability of this system as a student attendance tracker aims to improve discipline among them. It also acts as a method to reduce the use of paper as an Adiwiyata model school (Adiwiyata: cares about the cleanliness, beauty and health of the environment). The e-money tab as an attendance 
tracker is a new invention. Past studies have explored the use of fingerprint and SMS Gateway digital attendance tracker systems.

Problem of Study

Previously, schools have not been using technology optimally. For example, the use of paper-based methods of attendance tracking that has not been changed. This can be seen as a method that is not as effective, as parents are unable to directly observe whether their children have arrived in school and if they were punctual. This is in accordance to (Wibowo, S., 2018: 1094) who mentions that the use of paper-based attendance methods lead to difficulties in parents knowing their children's rate of attendance, sick leaves, permit leaves, missed classes as well as lateness in schools. With the advancement of technology, schools can now develop a digital attendance tracking system. This facility can support Elementary School of Muhammadiyah 1 Ketelan Surakarta as a technology-based school.

\section{State of the Art}

These past studies were done by Diartono (2010: 81 ), which concluded that this system is beneficial for monitoring attendance of students in school. The e-money tab is internet based, and thus if it is not connected to the internet, the tablet is unusable. This study is in line with Prasongko \& Dewi (2015: 18), who mentioned that the use of a web based attendance tracker application system is able to improve the speed and ease of attendance report development, allowing it to be done in 20 minutes. The novelty of this study is that it conducts surveillance and records students' attendances using the e-money tab and is directly connected to the parents' mobile phones. Using the WhatsApp application, parents will be sent their children's attendance information. If students are not present at school without explanation, then the application will automatically notify the parents, allowing them to follow up with their children at home (Mubarok, A., 2017: 231).

\section{Gap Study \& Objective}

Based on the presented study problem, the author is now conducting a study observing the use of e-money tab as an attendance tracker. The following includes some focus of the study: 1) The process of e-money tab use as an attendance tracker that improves building in students. 2) the advantages and disadvantages of the use of e-money tab as an attendance tracker in building discipline in students. 3) the impacts of e-money tab use as an attendance tracker in building discipling of students.

\section{METHOD}

This study is a qualitative study using a phenomenological research design to explore the use of e-money tab as an attendance tracker in building discipline in students. According to Creswell (2010: 20), a phenomenological study observes humans and identifies their experiences when faced with a certain phenomena. This study was conducted in Elementary School of Muhammadiyah 1 Ketelan Surakarta that is located at 1 Kartini Street, Ketelan, Banjarsari, Surakarta. Subjects of this study include the IT team, principal of the school and the students of the school. The object studied is the use of the e-money tab as an attendance tracker. The study was done on 19th and 24th June 2010.

The author collected data by: 1 ) interview method, the author enquired about the use of the e-money tab as an attendance tracker in building discipline in students, the advantages and disadvantages associated with the use of e-money tab as an attendance tracker in building discipline in students as well as the impacts of the use of e-money tab as an attendance tracker in building discipline in students. 2) observation method, by observing the process of using the e-money tab as an attendance tracker in building discipline in students. 3) assessment of documents method, done to collect data regarding the use of the e-money tab as a student attendance tracker, notification of attendance 
through whatsapp and the interface design of the e-money tab on the computer. The validity of data collected in this study was tested using triangulation of technique and data source.

Triangulation of techniques were conducted by comparison of data collected from interviews, observation and assessment of documents on the use of the e-money tab as an attendance tracker by students, the principal and the IT team at Elementary School of Muhammadiyah 1 Ketelan Surakarta. Triangulation of data sources in this study was done by checking data collected during interviews on the use of the e-money tab as an attendance tracker with sources including students, the principal and the IT team at Elementary School of Muhammadiyah 1 Ketelan Surakarta.

Analysis of data was done using the Miles Huberman model, in which several things is conducted, including: 1) reduction of data, done by the author to summarize, choosing only core components and focusing on important points regarding the analysis of the use of emoney tab as an attendance tracker in building discipline in students. 2) presentation of data was done by including data correlated to the use of the e-money tab, advantages and disadvantages, and the impacts of e-money tab use. 3) verification of data, the author concluded analysis results from data obtained regarding the use of e-money tab as an attendance tracker in building discipline of students in Elementary School of Muhammadiyah 1 Ketelan Surakarta.

\section{RESULT}

Elementary School of Muhammadiyah 1 Ketelan Surakarta have implemented the use of an online attendance tracker using the e-money tab since the beginning of the 2019 academic period, and it has been running well as hoped by the school. The e-money tab is developed based on the e-money card, which is the main method of transaction in the school. In line with the thoughts of (Wulandari, D. 2018: 1928), who mentioned the use of electronic money as a transaction method is now becoming a trend in Indonesia. In this era of advancing technology, schools are demanded to develop digital facilities that improve the quality of education. This is similar to the study by (Budiman 2017: 41) that explains the global demand for education to keep up with technological advancements to improve quality. In the future, schools must be able to utilize technology in all its processes. Schools must also be able to provide technology education to students from a young age to allow them to be able to develop with new technologies in the future. To support the digital era, Elementary School of Muhammadiyah 1 Ketelan Surakarta launched electronic based facilities such as e-infaq, e-library, e-learning, and e-money tab.

Table 1. Results of interview regarding the impacts of e-money tab use as a student attendance tracker

\begin{tabular}{ccc}
\hline No. & Subject & \multicolumn{1}{c}{ Interview Results } \\
\hline 1. & Subject 1 & $\begin{array}{l}\text { States that students have become more disciplined and } \\
\text { have a better understanding of technology. }\end{array}$ \\
\hline 2. & Subject 2 & $\begin{array}{l}\text { States that with the } \text {-money tab as an attendance tracker, } \\
\text { it has made the students be more disciplined. }\end{array}$ \\
\hline 3. & Subject 3 & $\begin{array}{l}\text { States that the e-money tab can minimize the frequency of } \\
\text { lateness in students so that they are more disciplined. }\end{array}$ \\
\hline
\end{tabular}


As shown on picture 1 , the e-money tab is a student school attendance tracker that utilizes e-money cards and a tablet. Attendance is recorded in the morning when students arrive in school and in the afternoon when they leave school. When a student scans their emoney card on the tablet, their individual identities and information of their attendance will be recorded. At the same time, this information will be sent through WhatsApp to their class teachers and parents. With the existence of the e-money tab, students are pushed to be disciplined in coming in on time. The following shows the process of using e-money tab as a student attendance tracker that is observed in this study:

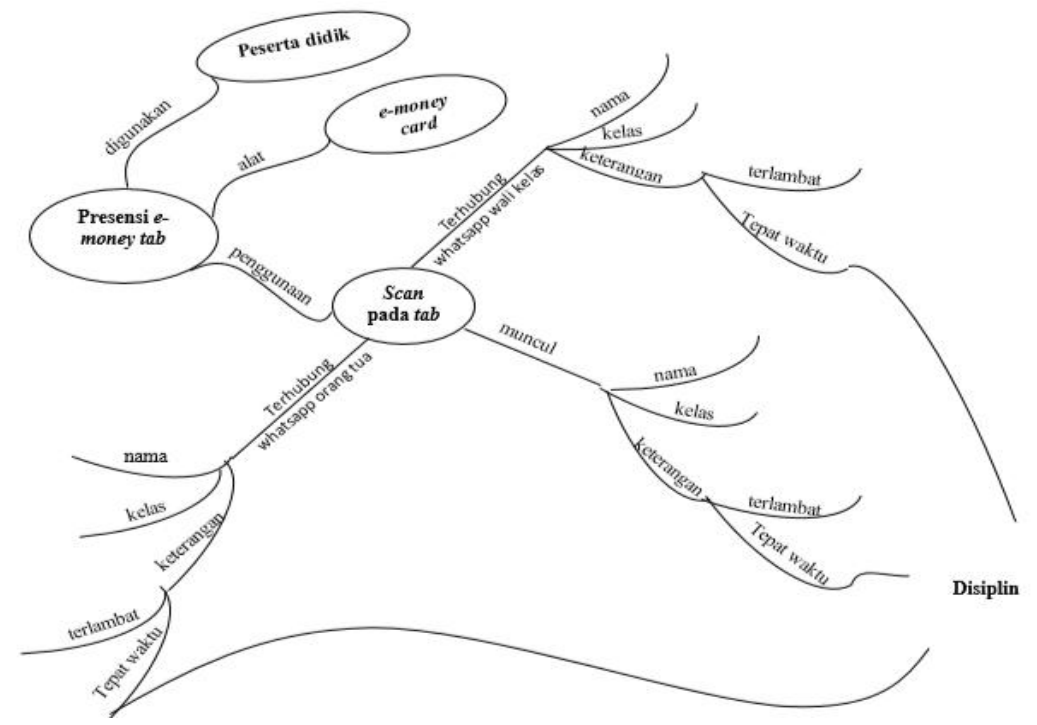

Figure 1. Process of using e-money tab by students

The e-money tab is developed as an attendance tracker to shape students to become more disciplined in coming to school on time. As written by (Nani, 2020: 8), the use of a fingerprint based attendance tracker for office workers in Sorawolio subdistrict tends to improve discipline of staff in arriving on time. This was supported by written data that was recorded with extensive details on the arrival and departure times of the staff. The utilization of the e-money tab as an attendance tracker would ease both teachers and parents in supervising students while they are at school. This is in line with the study by (Rahayu, 2018: 39) that states that the use of the fingerprint application system eases work performance by the administrative team, lecturers and parents of students in monitoring university students' attendance. Therefore, it is believed that the use of the e-money tab as an attendance tracker can be used to improve work performance of teachers in processing attendance data and in overseeing the discipline of students in school.

\section{DISCUSSION}

The process of e-money tab use in Elementary School of Muhammadiyah 1 Ketelan Surakarta

The use of the e-money $t a b$ as an attendance tracker in Elementary School of Muhammadiyah 1 Ketelan Surakarta is an effort to introduce technology to students while they are young to improve the quality of the school as a model technology-based institution. The use of e-money tab as an attendance tracker can also improve work performance of the teaching staff in processing attendance data, as well as eases both teachers and parents in overseeing the students while at school. This corresponds to the study by (Mubarok, A. 2017: 234) that states that attendance tracking facilitating an sms gateway system eases 
teachers in supervising the actions of students as there is multiple surveillance, both from the teachers and from the parents preventively. The e-money tab is used as an attendance tracker that has been functioning for over one year as it was started early since the beginning of the 2019 academic period.

Before the e-money tab was used as an attendance tracker, the IT team first conducted socializations to the principal, teachers, parents and students. This socialization was conducted through spreading written notices and a live demonstration of how to use the $e$ money tab. With these, the principal, teachers and students became familiar with the right and proper use of the e-money tab. This is similar to the study by (Asmira, 2016: 1017) that states that socialization and training of the use of a fingerprint-based system followed initially by some and then the rest of the staff led to the successful implementation of the system. Students were very enthusiastic with the use of the e-money $t a b$ as an attendance tracker, and this improved their discipline. This is in accordance with the study by (Wulandari, 2019: 109) that states that the implementation of the fingerprint system was followed with positive response from the staff and was effective in improving their discipline. Attendance was tracked every day in the morning when students arrive and when they leave school. This is comparable to the study by (Inayatillah, 2015: 28) that stated government employees and lecturers conducted attendance scanning twice in a day according to their arrival and departure times. With the existence of the e-money tab as an attendance tracker, we have seen a reduction in students that arrive late. The school implemented a code of conduct that stated that students attending school past 07.15 WIB are said to be late, and thus classified as not disciplined because of tardiness.

\section{Advantages and Disadvantages of the e-money tab in Elementary School of Muhammadiyah 1 Ketelan Surakarta}

One of the advantages of using the e-money tab as an attendance tracker in Elementary School of Muhammadiyah 1 Ketelan Surakarta is as part of the school's technology development. This is similar to the study by (Budiman, 2017: 32) that says that the development of technology in this globalisation era impacts the field of education. Thus, there is a global demand for the education sector to evolve its use of technology to improve its quality. The use of the e-money $t a b$ as an attendance tracker allows parents to easily monitor their child as attendance is directly connected to the parents' WhatsApp. This is similar to the study by (Putra, 2018: 168) that states the use of a fingerprint based system as an attendance tracker that is connected with the Global System for Mobile Communications (GSM) server allows attendance to be informed to parents.

A disadvantage to the use of the e-money tab as an attendance tracker is that if the student loses their e-money card, they would need to report this and change into a new card. This is similar to what was reported by (Sujana, 2019: 11) that states that users would need to make a new card if their original e-money card is lost. Another disadvantage happens when multiple attendances are recorded at the same time, which causes the network to lag and a delay in the sending of notifications to parents through WhatsApp. This issue was also highlighted in the study by (Prasongko, 2015: 14) that states that attendance notification to parents sent through SMS gateway was only delivered after five minutes and requires credit in the modem and signal from the provider.

\section{Impacts of using e-money tab in Elementary School of Muhammadiyah 1 Ketelan Surakarta}

The use of the e-money tab as an attendance tracker allows teachers and parents to easily conduct monitoring. Teachers no longer need to oversee each student one by one while at school. This is similar to what was found by (Mubarok, 2017: 233) in which the 
implementation of the SMS gateway based system eased teachers in maintaining and overseeing students that violated school rules. Using the e-money tab, there is a good system of communication between parents of the students with the school staff through notifications on WhatsApp. This also assists parents in monitoring their children while at school, and prevents the need for them to personally chat with the teachers to ask for information about their children. This was also found in the study by (Mubarok, 2017: 231) in which online applications plays a bridging role between parents and the school by attendance tracking through an application the automatically informs the presence of the students or violations that they may have done at school.

Evaluation and repairs on the e-money tab system is conducted routinely annually as well as whenever a problem occurs. This annual checking is conducted as a demand from the school to always keep on developing their program each year. This is in line with the study by (Fakih, 2015: 43) that states that evaluation is done to evaluate the attendance tracking information system to solve problems that are present in the conventional attendance system previously used. The e-money card acts as a main transactional tool in Elementary School of Muhammadiyah 1 Ketelan Surakarta. Aside from being used as an attendance tool, the e-money card is also used in buying food, drinks and stationeries at the school-owned company (BUMS - Badan Usaha Milik Sekolah), as well as for infaq payment at school and borrowing of books from the library.

\section{CONCLUSION}

\section{Novelty and Contribution}

In conclusion, this study has found that a) the use of e-money tab as an attendance tracker is a means of improving school quality as a technology-based model school. The emoney tab is an extension feature build from the e-money card and can only be accessed in schools with a strong internet connection, b) the e-money tab has several advantages, among which are the feature to record attendance of all students, allowing teachers to oversee students' disciplines and parents to monitor their children's arrival and departure times at school. On the other hand, the disadvantages to the use of the e-money tab is the likelihood for its server to become error prone, especially when used by multiple students at the same time and without a stable internet connection. c) The impact of this e-money tab as an attendance tracker is that it is able to help build discipline in students.

\section{Limitation and Future Study}

For future studies, there is a need for deeper studies of the use of the e-money tab as a student attendance tracker. For the government, it is hoped that the implementation of the e-money tab as an attendance tracker that can build discipline in students can be done in all schools.

\section{Implication / suggestions}

Some recommendations are presented by the author to different parties, among which are: 1) For the students, they must be able to improve discipline through the use of the emoney tab as an attendance tracker. 2) For schools, they must be able to improve the speed of their internet network so that the e-money tab system can be used maximally. In addition, schools should be responsible in adding on the number of tablets available to avoid lines during attendance recording as well as to reduce the amount of time needed. 3) For the school principal, they need to continue motivating and pushing students to improve discipline in schools. 4) For the IT team, they need to continuously study and follow the development of digital technology as to solve problems related to the use of e-money tab as a student attendance tracker. 


\section{REFERENCES}

Abbas, S., \& R. (2018). "Punishments To Strengthen Students' Discipline for Future Education." Advances in Socis/ Science, Education and Humanities Reserch 125.

Annisa, F. (2018). "Planting Of Discipline Character Education Values In Basic School Students." International Jurnal of Education Dynamics 1(1): 109.

Asmira. (2016). "Efektivitas Penerapan Absensi (Fingerprint) Dalam Meningkatkan Disiplin Kerja Pegawai Di Kecamatan Anggana Kabupaten Kutai Kartanegara." Journal IImu Pemerintahan 4(3): 1017.

Budiman, H. (2017). “Peran Teknologi Informasi Dan Komunikasi Dalam Pendidikan.” Jurnal Pendidik Islam 8(1).

Creswell, J. W. (2010). Research Design Pendekatan Kualitatif, Kuantitatif, Dan Mixed. Yogyakarta: Pustaka Pelajar.

Diartono, D. A. (2010). “Integrasi Sistem Presensi Finger Print Dan Sistem Sms Gateway Untuk Monitoring Kehadiran Siswa." Jurnal Teknologi Informasi 15(1).

Fakih, A., Dkk. (2015). "Pemanfaatan Teknologi Fingerprint Authentication Untuk Otomatisasi Presensi Perkuliahan." Journal of Information System Engineering and Business Intelligence 1(2): 43.

Inayatillah. (2015). "Dampak Penerapan Absen Sidik Jari (Fingerprint) Terhadap PNS Perempuan Di Lingkup UIN Ar-Raniry Banda Aceh." Internasional Journal of Child and Gender Studies 1(2): 28.

Minsih. (2015). "Pelaksanaan Layanan Dasar Bimbingan Dalam Membentuk Karakter Siswa Di SD Muhammadiyah Program Khusus Kota Surakarta." Profesi Pendidikan Dasar 2(2): 112 .

Mubarok, A., \& Santoso W. H. (2017). "Penerapan SMS Gateway Sebagai Alternatif Peningkatan Kedisiplinan Siswa Di SMK Anwarul Maliki Sukorejo Pasuruan." Jurnal Pendidikan Agama Islam 2(2).

Nani, A. Dkk. (2020). "Efektivitas Penerapan Absensi Fingerprint Terhadap Disiplin Pegawai Di Kantor Kecamatan Sorawolio Kota Baubau." Jurnal Studi IImu Pemerintahan 1(1): 8.

Prasongko, C., \& Dewi, S. (2015). “Aplikasi Presensi Siswa Berbasis Web Yang Terintegrasi Dengan SMS Gateway Studi Kasus SMP Muhammadiyah 4 Yogyakarta." Jurnal Sarjana Teknik Informatika 3(1): 14.

Putra, D. S., \& Ami F. (2018). “Perancangan Aplikasi Presensi Dosen Realtime Dengan Metode Rapid Aplication Development (RAD) Menggunakan Fingerprint Berbasis Web." Jurnal Pengembangan IT 3(2): 168.

Putra, R. A. W., Dkk. (2019). "The Role Of School's Rules In Forming Student Discipline Behavior At State 2 Elementari School Sendangsari Sub District Batuwarno Wonogiri District Year Lessons 2019/2020." Civis Education And Social Sciense Jurnal 1(1).

Putri, D. P. (2018). "Pendidikan Karakter Pada Anak Sekolah Dasar Di Era Digital." Jurnal Pendidikan Dasar 2(1).

Rahayu, M. I., Dkk. (2018). "Pengembangan Sistem Informasi Presensi Perkuliahan Di Fakultas Teknik Mesin Dan Dirgantara Institut Teknologi Bandung." Jurnal Teknologi Informasi dan Komunikasi 7(1): 9.

Rahmawati, Heni. (2020). “Analasis Penerapan E-Rapor Dalam Penilaian Kurikulum 2013 Di SD Muhammadiyah 1 Ketelan Surakarta Tahun 2019/2020." Universitas Muhammadiyah 1 Ketelan Surakarta.

Samino. (2015). Filsafat Pendidikan Rujukan Bagi Pendidik Dan Calon Pendidik. Kartasura: Duta Permata Ilmu.

Sujana, D., Dkk. (2019). “Komparasi Analisa Sistem Simulasi Vending Machine Autimatic Cash Money Dan E-Money Di Universitas Islam Syekh Yusuf Tangerang." JUTIS 7(1): 11. 
Sukmadinata, N. S. (2011). Landasan Psikologi Proses Pendidikan. Bandung: PT Remaja Rosdarya.

Wibowo, S., \& S. (2018). "Analisis Dan Perancangan Sistem Informasi Presensi Siswa Berbasis Android Pada SD Dan SMP Kanaan Global School Jambi." Jurnal Manajemen Sistem Informasi 3(2).

Widyahening, E. T., Dkk. (2016). "Literary Works and Character Education." International Journal of Language and Literature 4(1): 177.

Wulandari, D., Dkk. (2018). "Factors Affecting The Adoption Of Electronic Money." International Jurnal of Civil Engineering and Technology 9(7): 1928.

Wulandari, D. (2019). "Respon Aparatur Sipil Negara (ASN) Mengenai Kebijakan Absensi Fingerprint Dalam Mendisiplinkan Pegawai." Institut Agama Islam Negeri Bengkulu.

Wuryandani, W., Dkk. (2014). "Pendidikan Karakter Disiplin Di Sekolah Dasar." Cakrawala Pendidikan (2). 